\title{
The History of Roman Durrës (I-IV E.S.)
}

\author{
Arlind Kasa \\ PhD Candidate, Faculty of Business, "Aleksander Moisiu" University, Durrës, Albania \\ Email: arlindkasa2@gmail.com
}

\section{Doi:10.5901/ajis.2015.v4n2s2p28}

\section{Abstract}

The main purpose of this presentation is to review and reappraise of the ancients fonts with new archaeological found discovered recently in Durrës, in these fifteen years. The city of Durrës in ancient periods was named Epidamnos, after Dyrrachium in Roman period and now Durrës. I will discuss for the roman colonization in Dyrrachium, when he was founded, why was changed the name in roman period, why Dyrrachium lost his independence and what had happened in Dyrrachium during Imperial Roman Period based in new archaeological found that had helped to reappraise of ancient authors.

Keywords: hellen colonization of Epidamnos, Illirian people in Epidamnos, Dyrrachium, Imperial Roman Period.

\section{Introduction}

Epidamnos-Dyrrachium were the names that Durrës had in ancient periods. The researchers are in one mind that these two names tell two different part of the city. Thucydidis had told us that Epidamnos was founded by Greek colons from Corcyra and Corinthin 627 B. C (Thycydides, 2002).

Another question for to discuss is: Epidamnos and Dyrrachium were one or two different city? Today exist three theories that treated these problem. The first, is that Epidamnos and Dyrrachium was an only city, which in early period was called Epidamnos and when Durrës was invaded from Rome, they changed the name in Dyrrachium because the name Epidamnos was sinister for roman than remembers the word damnus (bad) (Melae, 2002; Plinus, 2002; Appiani, 2002).

Another theory has Koço Zheku, an Albanian archaeologist. He belive that Epidamnos was a city where was established Greek colons from Corcyra and Corinth in 627 B. C. He had located the city of Epidamnos at "Kepi i Lagjit", actual Turra Castle in Kavaja, while Dyrrachium he had located in actual Durrës (Zheku, 1997). Author didn't had analysed same ancients resources and he had produced another history of ancient Durrës. Koço Zheku belive that Dyrrah was inhabited immediately after Peloponnesian War. This theory don't has a solids archaeological and historical evidence.

The third theory was that Epidamnos and Dyrrachium was two different cities very near each other and frequently the two cities were called or Epidamnos or Dyrrachium from visitors, traders or strangers. The researchers based these theory at Appiani, who had telled a history why Durrësi in ancients periods had two different names. According to legend, Epidamnos was a king that built a fortress, that took his name in actual hill of Durrës. His daughter, after was marriaged with Poseidon, she had born a child with name Dyrrah, who built a sea station in botto hill (Appiani, 2002). With passing the time, economical and political development made that these two different cities linked up an only city.

The Greeks had came and established in 627 B.C. in Durrës because they were interested for traded with locals and for the geographic position. The colonizers were with origin from Corcyra hence Epidamnos, who had considered Corcyra as mother-town (Thucydides, 2002). The trades was much profitable, which brought for established a colony and had erected the poletes institutions (Plutach, 2002). Poletesis, a person from Epidamnos, who was selected by city-state of Epidamnos for made trade with Illyrians, the people that had lived near Epidamnos. Poletes was created after was established the colony. The ancient authors didn't have told us when was erected this institution.

\section{The Problem}

We had some problems for made these paper. We were based at the ancient authors but they didn't had indicated much about Epidamnos-Dyrrachium. These ancient sources didn't had spoken about habitants of Epidamnos-Dyrrachium in ancient periods, for their political system of government, economy, social life, daily rutine, city planning etc. but they had 
mentioned Durrës only in war situations. This didn't help us to understood all the history of Dyrrachium. Some of these deficiencies we will complete with archaeological excavation that were made in Durrës. The archaeological data had told us some informations about Epidamnos-Dyrrachium during ancient period but didn't had indicate all Durrës history. Some data had lost forever.

\section{Purpose}

The new archaeological finds help us for understood the history of Dyrrachium and for completed those part of history that the ancients authors didn't had spoken in their books. We be in needs that still did't was told all story of Durrës. The future archaeological exploration will help to develop the ancient story of Durrës.

\section{Hypothesis}

Here I will speak about the history of Dyrrachium with a new view. This will tell us that this ancient city was one of the most important in Albania.

\section{Methodology}

For this important city, had spoke much ancient authors and after Second World War were made much archaeological excavations. I will analyze the informations that the ancient authors had given and when they were silent in same situations. I will base in the archaeological excavation that were made in Durrës by albanian archaeologists for completed the history of the city.

\section{The history of Epidamnos before Roman invasion}

Epidamnos in antiquity, before Roman Invasion, was an independent city. At the beginning of his history, Epidamnos was depended from her city-mother Corcyra. This was understandable because he was a new city with much problem, with weak government institutions that had needed for supports and colonizers were from Corcyra etc. With passing the time Epidamnos won more independence from Corcyra. This believed that had happened in VI century B.C. The Epidamnos was governed from his institutions that were consolidated.

The ancient authors didn't had told us much about Epidamnos government institutions. They had mentioned the Epidamnos gonverment institutions in some cases and only when was necessary for compared with some Greek institutions. From these few date we had lerned some institutions and we had understood how was governed Durrës in antiquity.

Epidamnos in antiquity had an oligarchy government system (Thycydides, 2002) where in top of the state was arhonti (Aristotelis, 2002). This told us that in Epidamnos the few governs the masses and the offices were occupied by the reaches people of the city, positions that was inherited by their childers. Epidamnos had a constitution that with passing the time had changed. The city was governed by chiefs clans, Fylarh. So, we had understood that the habitants of Epidamnos were divided in clans, where every clan chose a tribesman who must represents the clan in assembly of the chiefs clans. But in a later period, unfortunately Aristotle didn't had told a date, the institution of the chiefs clans, was substituted from Boule, the Council Chamber of the city. Perhaps this change was made because the Epidamnos habitants desiderated to changes the government system of the city. We thinks that this had happened in an abundance period of the city, perhaps in the end of VI century B.C. and at the began of V century B.C. when other social stratums, for example craftsmen and trader, must were consolidated and riches from trade. This was demonstrated when a ferryman from Epidamnos who was called Kleosten, won a carriage race in sixty six Olympic games (Pausaniae, 2002).

Now, the other social stratums want to were part of the government. Presumably, they had increased their intents because the constitution was changed, with erected the Boule institution. In any case, the aristocracy had a great influence in govern so Aristotle express, the elite must take part in election (Aristotelis, 2002).

How had told Scymni, near Epidamnos were the Illyrians tribes (Scymni, 2002), who Epidamnos habitants made trades. The Epidamnos citizens had fear by Illyrian tribes. Therefore was erected the Poletes institutions, who was elected every year and he was selected by famous person, who went to Illyrians in the name of citizens and he made trade with they. Because he went there, he was called Poletes. Also, in the Epidamnos Constitution was sanctioned that the slaves was state property (Aristotelis, 2002). They were under the state patronage and they were stored from abuse, 
kill and ill-treatment of their patron. The Epidamnos habitants had authorized Illyrians that could lived in the town (C. Aeliani, 2002). Hereby, over time the number of Illyrians in Epidamnos was grew. This was documented in ancient Epidamnos-Dyrrachium cemetery, where were discovered Illyrian elements in Hellenistic tombs (Hidri, 1986; Hidri, 1996; Hidri, 1997; Toçi, 1965).

With pass the time in Epidamnos began the disagreements between Oligarchs and Democrats. This caused a civil war which finished with oligarchs victory that were helped by Corcyra (Thucydides, 2002). After the war, Corcyra sent their colons in Epidamnos (Diodori, 2002). The civil war of Epidamnos was one of the causes that had influenced for started the Peloponnesus War in 431 B.C. in Greece (Thucydides, 2002).

The city of Epidamnos didn't was mentioned by the ancient authors for long time. He was mentioned in 314 B.C. when the Macedonian king Cassander had attacked and had conquered Epidamnos but in 312 B.C. with helps of Corcyra and Illyrians Taulant tribe the city of Epidamnos stood under Illyrian king Glaucia govern (Wilkes, 2005). Epidamnos stood under Illyrian also in time of his son, Monunius and his nephew, Mytilus. This was documented from coins that these two kings had fabricated with their names and with Illyrian state symbols together with symbol Dyrr (namely Dyrrah) discovered by Albanian archaeologists in Durrës (Ceka, 2008). After Mytilus die, Epidamnos won his independence, about the middle of III century B.C. Probably this had happened when the Taulants lost their powers over other Illyrian tribes. This had coincided with Ardiaean appearance, another Illyrian tribe, and had took the command at other Illyrian tribes, include also Taulant. This situation must was used by Epidamnos habitants for declared their independence from Illyrian Kingdom.

Illyrian Kingdom was really interested for Epidamnos and few decades after independence, in 229 B.C., the Illyrian Queen Teuta had decided to invade Epidamnos, who had called Roma for help. This had caused the start of the war between Illyrian Kingdom and Rome, that was concluded with Rome victory (Polybii, 2002).

With entry under Roman protection after First Illyrian-Roman War in 229-228 B.C., Dyrrah was used how port for roman future incursions in Balkans. This was the role of Dyrrah for the other two centuries. Other conditions between Roma and Epidamnos were payment of some tax and for sent soldiers when Roma required. These was the conditions that Epidamnos habitants had signed with Romans for their help in the war and for Roman protection.

The city of Epidamnos after fall of Illyrian and Macedonian kingdoms by Roma in II century B.C., didn't was mentioned by ancient authors. In two century following the town had preserved his independence and government institutions that were evident from coins (Ceka, 2008) that were discovered by Albanian archaeologists at excavations in Durrës. Only an independence state could cut coins and only a state had his government institutions, his army, laws, etc. During these periods the name Dyrrah must was used more than Epidamnos. This perhaps had happened from fact that Romans had used the port of Dyrrah and didn't had past from Epidamnos that was situated in the top of hill. For two century the romans had called the city with the name of the port Dyrrah, where they disembark. When the political and economical center had moved from Greece to Italy, the port of Dyrrah took a great importance for the romans and the name of the port must had dominated on fortes name. The majority of visitors, traders, armies, political and economical contact were with Italian Peninsula now. This had conditioned also ancient authors because now the writer were from Italy that writes for Dyrrah. This was associated with decline of Greece Polis. The importance that Dyrrah had for Roma was evidenced with construction of Via Egnatia, which began from Dyrrah and Apollonia and ends in Constantinople. Bilingual inscriptions at the milestones record that Gnaeus Egnatius, Proconsul of Macedonia, had ordered the construction of the road, perhaps had took his name from his builder (Ceka, Papajani, 1971). This road brought benefits for Dyrrah because had influenced trades between Dyrrah and other part of Balkans.

Must pass two century that Durrës was mentioned by ancient authors, but now was called Dyrrah or Dyrrachium and not Epidamnos. The first author that had mentioned Dyrrachium was Cicero, a noted antiquity orator. Dyrrah was in his patronage that was represented in Roman Senate. Cicero was the Masterwhilst of Dyrrah and Buthrotum, especially the elite of Dyrrah were his clients (Deniaux, 1988). This situation was normal in Roman World and didn't was only a Dyrrah caracteritic (Harman, 1957).

The city of Dyrrah was arena where had happened the Civil War between G.J. Caesar and Pompey. After G.J. Caesar had marched with his legion for Roma, Pompey, Roman Consuls and the majority parts of Senate had escaped from Italy and they had went in Dyrrah (C.V. Paterculi, 2002). Exactly, in Dyrrah had happened one from the most important battle between G.J. Caesar and Pompey. Pompey after taught for events that had happened in Orikum and Apollonia, he had frightened for Dyrrah and he had traveled days for arrived as soon as possible. Pompey had placed his camp on a high location that was called Petra, today Kavaja rock. After continuous attacks that Caesar made, he didn't arrived to conquer Dyrrah, which was well fortified and he was defended from the Pompey army. After defeat Caesar retired in Pharsalus (Cesar, 2002; Appiani, 2002; Lucani, 2002; Cassii, 2002). The battle of Dyrrah was one of few battles 
that G.J. Caesar had lost in his military career. The Dyrrachium people were in aleance with Pompey and had fought against G.J. Caesar. Exactly, this alliance will was fatal for Dyrrah because G.J. Caesar had won against Pompey in Pharsalus and had took the power in Rome. He didn't initiated any punishment for the city of Dyrrah and his people. Ancient authors did't had told us nothing. If G.J. Caesar had made reprisal in Dyrrah, they would told. This had made us to believe that he didn't took any reprisal. Otherwise, the ancient authors must told for the reprisals but they were silent.

After G.J. Caesar was killed, the power was heredities by his nephew Octavianus, who about 30 year B.C. removed the independence of Dyrrah and he had transformed in a Roman colony. The ancient author told also why Octavianus Augustus had removed the independence of Dyrrah. After G.J. Caesar die some Illyrian tribes fought against Roman because they had believed that the roman power had born and die with G.J. Caesar. They had destroyed five Roman army units under Vatianus command, a roman general. Then, Vatianus with remains army returns in Dyrrah (Appiani, 2002). The soldiers that were in Dyrrah were indignanted with he and had advantaged by Vatianus was sick, they abandons he and they were united with M.J. Brutus (Cassii, 2002). With these soldiers and his army M.J. Brutus had attacked his enemy, Octavianus Augustus and Mark Antony.

On account of participations in alliance against G.J. Caesar and the union of roman soldiers from Dyrrah with G.J. Caesar assassins or perhaps the city council had made alliance with G.J. Caesar assassins. Ancient authors didn't told much about facts why Octavianus Augustus had declared Dyrrah Roman Colony. The inscriptions that Albanian archaeologist had discovered in Durrës from diverse excavations, we had understood the name of Roman Colony of Dyrrah. He was called Coloniae Juliae Augustae Dyrrachinis. These inscriptions were discovered in tombs of roman period in Durrës (Tartari, F., 1997) and to water pipes of roman period that distributes the water in the city (Miraj, L., 1991; Miraj, F., 1991).

\section{The history of Dyrrah under Roman dominance}

After had finished the war with G.J. Caesar assassins, where Octavianus Augustus and Mark Antony had won, they had decided to divides the Roman state, where Shkodra was boundary among Oriental part of Roman state that was governed by Mark Antony and the Occidental part was governed by Octavianus Augustus. Dyrrah was part of Orient under Mark Antony govern (Appiani, 2002), till Mark Antony lost the war with Octavianus Augustus.

After had defeated Mark Antony, Octavianus Augustus didn't had rivals. So, for diverse causes he "divided" the power with the Roman Senate, where the Senate governs the Provinces of Africa, Numibia, Asia, Greece with Epyrus, Dalmatia, Macedonia, Sicilia, Crete, Libya and Pont. Dyrrah was part of Macedonian Porvince and was under Roman Senate government. From this time the ancient authors didn't had mentioned Dyrrah form much time.

Although Dyrrah had lost his independence, he continue to was one of principal city that roman had used for passed from Apennine Peninsula in Balkans Peninsula for their political and economical motivations. This had happened from geographical position that had Dyrrah from Apulia, where the distance was 108 thousand mile (Strabonis, 2002), a short distance that had favored the contacts and the communications between two Adriatic coasts. The sea depth was minor than Ionian and the security from sea storm and others sea dangers was little. So, also the territory where was established Dyrrah up a high hill and unassailable, where was located a great abyss and flow a depth river (Malchi , 2002) must had made the peoples to feld to secure and quiet. These had influenced the trades, craftsmanship and exchange growths inside the city. This had influenced economic progress and prosperity growth of the Dyrrah people. So, also Pax Romana and customs privation in the Roman Empire had influenced the positively because Dyrrah was a port from where merchandises had past for the other parts of Balkans.

We didn't had forgetted the fact that from Dyrrah had began forward, during and after romans invade important roads that had connected Dyrrah with the other parts of Balkans. The first and the most important road was Via Egnatia, where one of starting-points was Dyrrah andit had finished in Constantinople (Itineraria Romana, Tabula Peutingeriana, 2002). Another road was it that had began from Salona, passes in all eastern coast of Adriatic sea and ends in Dyrrah. The third road started from Durrachium and ends in Sparta and island of Cythera (Itineraria Romana, Itineraria of Antonin August). So, Dyrrachium when was under roman domination was an important port and city, where were intersected th most important roads that had connected different part of Balkans. Thus, much products, raw materials, roman armies, instructions, traders and trades, political information that had came from Roma, initially must passed from Dyrrah afterward they had passed in other regions of Balkans. Dyrrachium was an important city in the east cost of Adriatic sea, he was a started point for some roads.

Some archaeological excavations in Durrës had found much importants data for understood some parts of Dyrrachium citizens. During Roman period Dyrrachium widen from the north part. In II centuries A.C. the city plan was 
organized in an orthogonal system. The houses of Dyrrachium citizens were organized in insulae maximally with five floors, where in the first floor were the tabernae, or the roman shops and manifactures, and the houses of the richs persons. In the other four floors were only the houses of the citizens. These insulae were discovered recently in some archaeological site in Durrës. They were constructed with bricks linked with mortar and it were covered with tiles roof.

The insulae were divided from a street system, that were building with stone plaques. In both sides were found sidewalks paved with stone plaques linked with mortar. In some areas the sidewalks were covered and in other parts didn't were. Under the sidewalks were the sewerage which had molding the sewage of the houses in the sea. These sewerage were constructed with bricks and was linked mortar.

Dyrrachium had the reputation of a city that was extended from earth at sea and it was indhabited from the two parts of hill and it had abundant from the earth and sea produces. Here it was possible that the inhaitants to were together island and continent habitants, to stands distant from bads that came from the both and to had benefits from the both (Gazae, 2002). In all his history, Dyrrachium was close of the sea and this had played an important role in the life of the city and the citizens.

Durrës had an uninterrupted life from ancient period to today. This was connected with some factors that had influenced the life over 2600 years. I will mention some of these factors. The more important factors were the sea and the geographic position. The sea was a communication instrument between Dyrrah and the other parts of Mediterranean. This had made that Durrës to was an important contact point where the navigators that cames from Italy initially must had passed from this city if they wants to went in other parts of Balkans, and conversely. Also the for the communications, trades and transports the sea offers diversity creatures where with could ates. Dyrrah was near the sea and was normal that exist in the city the fishermen (Aeliani 2002) and the products and sub-products of the sea must was present in the people eat table and in the market of Dyrrachium.

The economic factors were important and had influenced in lifespan of Dyrrah. Also economical factors that we had mentioned over, were other factors. Dyrrachium was a interesed region for trades between Illyrian and Macedonian peoples (Strabonis, 2002). We had understood that Dyrrah was an important point where the trades were made between two peoples. These economic communications had influenced the citizens prosperity growths. By ancient authors we had learned that Dyrrah citizens trades balisc, asari, irisi, saliunka and lapsana (Plini, 2002). Dyrrah was situated near resources and how an important port that he was, certainly must had exported these resources in other parts of Mediterranean. As we had spoken, the peoples of Dyrrah had elected a person from their aristocracy, who must made trades with Illyrians. This was called Poletes. He must made transactions with autochthons. This was proved from Dyrrah coins that were discovered in ancient city in Albania how Pelion, Apollonia, Scodra, Lissus, Bylis, Albanopolis, Berat, Skampa etc.

The geographical position and the economic progress had made that Dyrrah was threatened continuously from invasive and despoliation attacks. After civil war between Mark Antony and Octavianus Augustus, Dyrrah was attacked from Illyrians that were revolted against Roman in 6-9 year A.C. that were led by Bato. In a passage, Dionis Cassii had said "Bato of Delmatia made a campaign against Salona. He was heavily injured with a stone but had caused other damage in all Adriatic coast, until Apollonia of Illyria" (Cassii, 2002). From this attack also Dyrrachium must was attacked but the ancient authors didn't had told us, if Dyrrah wolud have resisted or not. After this event, Dyrrah didn't was mentioned by ancient authors. During I-II century A.C. we didn't knew what happens in Dyrrah. The ancient authors had spoke only for the fates of Roman Provinces of Macedonia and Illiric, where Dyrrah was part of the Province of Macedonia.

The ancient authors had mentioned the city only in middle IV century A.C. when Dyrrah was destroyed from a earthquake. According to ancients sources Dyrrachium was distroyed from the earthquake because of bads imoraliy of his peoples, he was distroyed by the gods ire (The name of ancient author is unknown. Description totius Mundi et Gentium, 2002). The earthquake was documented also from actual excavations in Durrës in the Amphitheatre (Miho,1984, p. 39; Miraj, 1986), in the Aquaduct (Miraj, Myrto, 1992, p. 150) and in the Public Thermea of Dyrrah (Miraj, 1991, p. 250). The period from I century A.C. to IV century A.C. was most flourish period of the city because in these period were constructed the greats monuments that were discovery in Durrës how the Amphitheatre, the Aquaduct, the Public Thermea, the Lighthouse, the Insulae, the city roads, the Roman Cemetery. These building had a huge cost in ancient period and only the greats cities had constructions such buildings. This demonstrate that Dyrrachium was one important city of Balkans. Based in an inscription that was found in Durrës we had knew that the Roman Emperor Hadrian had ordered the construction of the Dyrrachium Aquaduct (Miraj, 1991, p. 250). In these period, the area and the inhabitants of Dyrrah were increased. These had happened on account of growth of city prosperities.

In the III-IV century all Balkans was called Illiric and Dyrrah was part of Illiric Province. After Diocletian and 
Maximian had abdicated from the power in voluntary manner, their posts were took by their two Ceasars, Galerius and Constantinus, where Constantinus take Gallia, Italy and Africa whilst Galerius govern Illyricum, Asia and Orient (Eutropii, 2002; Aurelii, 2002; Orosi, 2002). Now Dyrrah was part of the Eastern Empire. From middle of century IV A.C. the Roman Empire had started to gave the first signs of separations in two part. In 395 the Roman Empire officialy was separate in two parts. She had two Emperors Flavius Honorius and Flavius Arcadius, where the first govern the Western Emperor and the second the Eastern Emperor of the Roman state. The Eastern Emperor inherit the area from Kyrene bounder in Lybia to Epidamn, who was located near lonian Sea and now was called Dyrrah (Caesariensis, 2002). This had happened in 395 year when the Roman Emperor Theodosius the Great had decided to separate the Roman Empire in two parts, where each part was governed by Theodosius sons.

During first century, Dyrrah was part of Macedonian Province but from IV century A.C., when all Balkans was called Illyricum, Dyrrachium was part of Macedonian Diocese where Thessaloniki was the capital and the Macedonian Diocese had seven provinces: Macedonia Prima, Praevalitana, Thessalia, two Epirus, Achaea, and Crete (Festi, 2002). The two Epirus were called Epirus Vetus and Epirus Nova. The confines between there was Vjosa river. We are interest for the province of Epirus Nova because Dyrrah or Dyrrachium was the capital. The Epirus was divided in two parts by Emperor Theodosius the Great, who gave the city of Dyrrah the authority of the city and the capital of the province (Malalae, 2002). Idem Emperor divide the Roman Empire in two parts in 395 A.C. and the Province of Illyricum, with Diocese of Macedonia. The province of Epirus Nova was included in Eastern Roman Empire that later was called Byzantine Empire.

\section{Conclusion}

Under Byzantine Empire, Dyrrah continued to conserve his status, the Capital of Epirus Nova. In V century A.C. the Balkans was named Prefecture of Illyricum, it was divided in two Dioceses, the Diocese of Dacia and the Diocese Macedonia. The Diocese of Macedonia was divided in six provinces: Macedonia, Achaea, Crete, Thessaly, Epirus Nova and Epirus Vetus (Notitia dignitatum tam civilium quam militarium in partibus Orientis, 1876). Dyrrah was still the Capital of Epirus Nova. This had told for the importance that Dyrrachium had in Late Antiquity. He was a great and an important city of Western Balkans, an important communication bridge between the two Empires. Unfortunately, the Ancient Authors didn't had told nothing about the city, his people, how they lives, the buildings etc., they had told only that he was the Epirus Nova capital. The Late Antiquity was a period of Barbarians Invasions and the period when the Western Roman Empire fall.

Another question was the expansion of Christianity in Dyrrah. The ancient sources didn't had told much about the expansion of Christianity in Dyrrah. They had spoke indirectly for Illyrian that were converted to Christianity (Sozomenus , 2002, p. 864) but didn't said anything about converted to Christianity of Dyrrachium people. So, we idn't had anything about Christianity spread in Durrës by ancient authors in I-V century A.C. Here could help the archaeological excavations that were did in Durrës, especially in Roman Cemetery of Dyrrah. Here were discovered tombs of roman period with symbol of Christian cross that were dated in III-IV century A.C. (Tartari, 2004), this help us to believe that Christianity must was diffused in Dyrrah during II-IV century A.C.

In IV-V century A.C. Dyrrah was mentioned only in war occasions. So, the ancient authors had told that the Diocese of Macedonia was attacked and it was invaded by the Barbarians tribes of Goth and Vandal (Aurelii, 1911, page 33; Eutropii, 1909, page 11; Orosii, 1899, page 22; Scriptores historiae Augustae, 1865, page 5). They had invaded also Epirus Nova and they had conquered the capital of the province, Dyrrah (Eusebius, 2002). The Barbarians had maintained under control these provinces for 15 year (Isidori, 1891, page 4). In V century A.C. the Ostrogoth that had headed by Theodoric, had attacked and they had invaded again Dyrrah, who had deserted by his habitants from fear of reprisal and slavery. The Ostrogoth had held Dyrrah under control for 3 year, from 479 to 482 A.C., when they were defeated by Sabinianus, a Byzantine general and Dyrrah enters again under Byzantine control (Malchi, 1870, page 411419). The ancient authors didn't had told anything whether habitants of Dyrrah were return in their house or not. From this period Dyrrah stood under Byzantine control for some century. He continued to was an important city, a bridge between Orient and Occident. Under Byzantine in VI century A.C. Dyrrah was the capital of Dyrrah Theme, when in Medieval Period Dyrrah had started to called Durrës.

\section{References}

Aeliani, C., (2002), "De Animalium Natura”, books XIII, XIV, llirët dhe lliria te autorët antik, Tiranë. Appiani, (2002), "Illyrike", llirët dhe lliria te autorët antik, Tiranë. 
Appiani, (2002), "Bella Civilia", books II, V, llirët dhe lliria te autorët antik, Tiranë.

Aristotelis, (2002), "Politica", books II, V, llirët dhe lliria te autorët antik, Tiranë.

Aurelii, V., S., (1911), "Liber de Ceasaribus", Teubneri, 1911.

Caesariensis, P., (2002), "De Bello Vandalico", book III, llirët dhe lliria te autorët antik, Tiranë.

Cassii C, D, (2002), "Historia Romana", books XLI, XLVII, LV, llirët dhe lliria te autorët antik, Tiranë.

Ceka, N., Papajani, L., (1971), "Rruga në luginën e Shkumbinit në kohën antike", Monumentet, 1, Tiranë.

Ceka, H., (1971), "Dega jugore e rrugës Egnatia", Monumentet, 2, Tiranë.

Ceka, H., (2008), "Monedhat e Dyrrahut dhe të Apollonisë", Akademia e Shkencave të Shqipërisë, Tiranë.

Cicero, (2002), "Epistolae. Ad Familiares", Ilirët dhe lliria te autorët antik, Tiranë.

Cesare, G., J., (2002), Bielli Civilis, book III, Ilirët dhe lliria te autorët antik, Tiranë.

Deniaux, E., (1988), "Ciceron et la protection des de l'Illyrie du sud et l'Epir", Illiria, 2, Tiranë.

Diodori, (2002), "Bibliotheca Historica", book XII, Ilirët dhe lliria te autorët antik, Tiranë.

Eusebius H., (2002), "Epistolae", llirët dhe lliria te autorët antik, Tiranë.

Eutropii, (1909), Breviarum ab Urbe Condita, book IX, X, Teubneri, 1909.

Tartari, F., (2004), "Varreza e shekujve I-IV të erës sonë në Dyrrah", Durrës.

Festi, (2002), "Breviarium rerum gestarum populi romani", llirët dhe lliria te autorët antik, Tiranë.

Malchi, (1870), "Byzantica", Teubneri.

Gazae, P., O., U., (2002), "Panegyricus in Imperatorem Anastasium" llirët dhe lliria te autorët antik, Tiranë.

Harman, L., (1957) "Un aspect social et politique du monde romain: le patronat, sur les collectivities publiques des origins au BasEmpire", Paris.

Hidri, H., (1986), "Nekropoli antik i Dyrrahut", Iliria, 2, Tiranë.

Hidri, H., (1996)“Veçori të ritualit të varrimit në nekropolin e Dyrrahut", Iliria, 1, Tiranë.

Hidri, H., (1997), "Disa të dhëna mbi topografinë e nekropolit të Dyrrahut", Iliria, 1, Tiranë.

Isidori H., (1891), "Historia Gothorum Vandalarum Sueborum", Berlin.

Itineraria Romana, (2002), "Tabula Peutingeriana", Ilirët dhe lliria te autorët antik, Tiranë.

Itineraria Romana, (2002), "Itineraria of Antonin August", Ilirët dhe lliria te autorët antik, Tiranë.

Lucani, M., A., (2002), "Pharsalia", book VI, llirët dhe lliria te autorët antik, Tiranë.

Malalae, J., (2002), "Chronographia", Ilirët dhe Iliria te autorët antik, Tiranë.

Malchi, (2002), "Byzantiaca", Ilirët dhe lliria te autorët antik, Tiranë.

Melae, P., (2002), "De Chorographia", book II, Ilirët dhe lliria te autorët antik, Tiranë.

Miraj, F., (1991), "Mbishkrime latine të Durrësit', Iliria, 1-2, Tiranë.

Miraj, F., Myrto, H., (1992), "Ujësjellësi i Dyrrahut", Illiria, 1, Tiranë.

Miraj, L., (1986), "Amfiteatri i Durrësit', Illiria, 2, Tiranë.

Miraj, L., (1991), "Mbishkrime për ndërtimet e Dyrrahut", Iliria,1-2, Tiranë.

Miraj, L., (1994), "Termat e Dyrrahu", Illiria, 1-2, Tiranë.

Miho, K., (1984), "Amfiteatri i Durrësit, Tiranë.

Orosi, P., (1899), "Historiae Adversus Paganos", book VII, Leipzig: 1899.

Paterculi, V., (2002), "Historiae Romanae", book II, llirët dhe lliria te autorët antik, Tiranë.

Pausaniae, (2002), "Descriptio Graeciae", book VI, Elida II, llirët dhe lliria te autorët antik, Tiranë.

Polybii, (2002), "Historiae", book II, llirët dhe lliria te autorët antik, Tiranë.

Plinus, (2002), "Naturalis Historiae", books III, XII, XIII, XIV, XIX, XX, llirët dhe lliria te autorët antik, Tiranë.

Plutach, (2002), "Quaestiones Graecae", llirët dhe lliria te autorët antik, Tiranë.

Scymni, (2002), "Orbis Descriptio. Evrope", Ilirët dhe Iliria te autorët antik, Tiranë.

Sozomenus, (2002), "Historia Ecclesiastica", Ilirët dhe lliria te autorët antik, Tiranë.

Strabonis, (2002), "Geographica", book VI, llirët dhe lliria te autorët antik, Tiranë.

Tartari, F., (1997), "Monumente funerare të shek. I-IV të e. sonë nga Durrësi, lliria, 1-2, Tiranë.

Toçi, V., (1965), "Të dhëna mbi topografinë dhe elementin ilir të Dyrrahut në dritën e zbulimeve të reja arkeologjike", Konferenca e Parë e Studimeve Albanologjike, Tiranë.

The name of ancient author is unknown, (1865), "Scriptores historiae Augustae", book XXIII, Teubneri.

The name of ancient author is unknown, (1876), "Notitia dignitatum tam civilium quam militarium in partibus Orientis", III, Berlin.

The name of ancient author is unknown, (2002), "Description totius Mundi et Gentium", llirët dhe lliria te autorët antik, Tiranë.

Thycydides, (2002), "History of the Peloponnesian War", book I, Ilirët dhe lliria te autorët antik, Tiranë.

Wilkes, J., (2005), "llirëe", Bacchus, Tiranë.

Zheku, K., (1997), "Epidamni dhe Dyrrahu në lashtësi ishin dy qytete të veçanta apo një qytet i vetëm me dy emra?", lliria, 1-2, Tiranë. 